\title{
Singapore's Struggle For Nationhood
}

$1945-1959 *$

DAVID MARSHALL

I was passionately involved in the activities of some of the years under review. No-one today can really recapture the intensity and fervour of total involvement by some of us during those years. I am no historian. To prepare this talk I have forced myself to read what others have written of this period - 1 find some major omissions in their accounts and assessments.

First and foremost we must recognize that it is not we, the people of Singapore, alone who achieved nationhood. Major credit must be given to the United Nations, which before, during and since this period kept up a consistent barrage of ever-increasing volume against colonialism, thereby acutely embarrassing imperial powers and encouraging liberation movements. Without the activities of the United Nations in this field we would today still be a colony.

The second major lacuna in historical assessment of the political development in this area is the failure to recognize that the British are a civilised people who played the game according to "Queensberry rules" and not according to the law of the jungle. The people of Singapore, living in a confined area which is easily controlled by a few machine-guns at a limited number of crossroads, would never have been able to achieve independence if the British had used bombs and bullets against us.

The third major lacuna in historical publications on the period is a total lack of recognition of the atmosphere prevailing in this area - an atmosphere created by the leprous concept that God is white and He created the white man in His image, and that we "the Asiatic natives" had the ineffable opportunity to pattern ourselves on the white man. This concept was drilled into us through the decades by governments, officials, schools, business institutions, and reinforced by the military and technocratic superiority of the white man, resulting in deracinating a vast majority of those who were exposed to these influences whilst creating passionate anger and revolt in the hearts of a few.

In the field of education the official approach was to produce only fodder required by the mercantile machine and, despite valuable contribution by missionary bodies, that was in fact the position till the beginning of the era under review. Education of the Malays was ignored, education for the Chinese immigrant was left to the devices of the immigrants. University education was denied us, and no effort was made to encourage even the few to study in universities abroad. This policy stemmed from the fear that we might imbibe the concepts of freedom and technocratic know-how which would upset the relationship of farmer and milch cow which imperialism regarded as the normal relationship of the white man and "Asiatic". Local industries were discouraged for fear that they might lessen the fat profits the white man garnered to repay his labours in the "graveyards of the tropics". This was one side of the picture.

On the other side British imperialism made tremendous contributions in the field of honest public administration, public health, and justice. Also, within the framework of racial arrogance, it introduced concepts of decent respect for one's fellow man and human values embodied in the political movement known as socialism.

In our society at the beginning of this era the English-speaking were mainly rootless culturally, and anaemic spiritually. The Malays maintained their dignity and self-respect by living in a closed-in society outside the mainstream of the imperialist cultural storm. The Chinese, principally immigrants and first-generation Singaporeans, through their schools and separate institutions and because of their vast numbers managed to retain their cultural identity and evolved a strong resentment against the racial arrogance of

-Text of a talk given at St. Andrew's Cathedral, Singapore on 12.7 .1969 in a series to celebrate the 150 th anniversary of Singapore. 
the white man. The young Chinese, with no tradition or education in democracy, seeking to establish his dignity as an individual, turned for a weapon to the newest movement in China - communism. The Indian, though equally restive, was better acquainted with democratic procedure and turned his aggressive reaction to trade unionism and socialist politics.

The constitutional position during the nine years from 1946 to 1955 was that in 1946 Singapore was completely divorced from mainland Malaya and became a separate colony. Betueen 1946 and 1948 it was governed by the Governor with an Advisory Council of officials and eleven unofficials, all nominated by him. In 1948 the Legislative Council included the Governor, 9 officials, 4 unofficials nominated by the Governor, 3 unofficials elected by the Chambers of Commerce, and 6 members elected by citizens of the United Kingdom and Colonies in a total population of nearly 300,000 . Out of a total electorate of 22,395 only $63 \%$ cast their votes. Above the Legislative Council was an Executive Council of 10 nominated members. In 1951 there was a further change which permitted the electorate to elect 9 members to the Legislative Council of 22 . Only $52 \%$ of an electorate of 48,155 voted. Such was the contempt even of the English educated. The Executive Council consisted of 12 members - 6 of whom were unofficial - all nominated.

At the commencement of this era it was the angry youths who initiated the struggle for nationhood through the Malayan Communist Party. Their concept of nationhood comprised Malaya and Singapore as an indivisible entity.

In December 1945 an English-speaking party known as the Malayan Democratic Union was formed in Singapore which, though co-operating and later allied with the Malayan Communist Party, was nevertheless essentially democratic in its approach, and genuine and fervent in its efforts to achieve independence. Despite its later excesses, this multi-racial party was originally both moderate in tone and reasonable and responsible in its plans for phased independence. Insufficient credit has been given to the stalwarts of this Party - John Eber, Lim Kian Chye, Philip Hoalim Sr., Lim Hong Bee - who carried the burden of rousing us to our pathetic state and seeking to extract reasonable concessions from an administration that was at all times a prisoner of a commercial community panting for more and more profits. Mr. Ford is alleged to have said once: "we do not make cars, we make profits". The colonial administration of Singapore could equally well have said: "We do not govern, we control and organise to enable our merchants to extract gold".

The Malayan Democratic Union allied itself with the Malayan Communist Party and various other organisations to form the Pan-Malayan Council of Joint Action in 1947. This was in effect the open front organisation of the Malayan Communist Party, and through 1947 till June 1948 kept up a broad constitutional struggle for independence within the British Commonwealth including mass meetings, demonstrations, hartals and foolishly (to my mind) a boycott of the 1948 elections. The platform of the Pan-Malayan Council of Joint Action was immediate re-unification of Singapore with Malaya, retention of Sultans, full citizenship for all who made Malaya their home, Malay as the official language with free use of other languages in and out of Parliament, a Council of Races to scrutinise Bills for possible racial discrimination, and a fully elected Parliament in Kuala Lumpur based on adult suffrage.

Unfortunately, in 1948 as a result of a new direction in international communist strategy, the Malayan Communist Party deserted the path of consitutional struggle and went on a rampage of virulent violence which for twelve years viciously caused death and destruction and ended in the loss of popular respect - at a high peak in 1945 - for the Malayan Communist Party itself. As a result of the conduct of the Malayan Communist Party, emergency regulations were introduced in June 1948. The M.D.U. dissolved itself and some of its leaders fled overseas. All constituent organisations of the P.M.C.J.A. were outlawed. Legitimate trade unionism and political activity received a serious setback. The ensuing period 1948-1953 saw the heyday of capitalist oppression of legitimate trade unionism in Singapore through arrests and detention without trial under the emergency regulations.

The Progressive Party was formed in August 1947 and represented mainly commercial and professional interests. It was English-speaking and multi-racial and 
limitcd its activitics to Singapore. It opposed merger with Malaya but proposed a confederation of Singapore, Malaya and the Borneo territories. In the election of 1948 it won 3 of the 6 seats and in 19516 of the 9 seats. The leadership was strongly proBritish and pro status quo, as was to be expected from commerical interests. To its credit, however, it must be said that it pressed for greater local representation in the Legislative Council and it first initiated proposals which later became the very valuable institution that we now know as the Central Provident Fund.

The Singapore Labour Party was formed in 1948 and its vicissitudes make extraordinarily difficult reading at this juncture. One of the moving spirits was Mr. Lim Yew Hock, a professional trade unionist who had been a nominee of the Governor in the 1948 Legislative Council. It was mainly composed of clerical workers and some local-born graduates. Again, this was a multi-racial party. In 1951 it had 2 of the 9 elected members of the Legislative Council.

The position in 1954 was that there was a growing underground movement for independence, spearheaded by communist agitation amongst students and workers, and an apathetic electorate contemptuous of the crumbs thrown out by the British.

Then came a new era with the Rendel Constitution. This provided for a Cabinet of the Governor and 9 others, including 3 officials - the Chief Secretary, the Financial Secretary, and the Attorney-General, whom 1 used to refer to as the "Gibraltar, Malta and Port Said of the Singapore Government" - an elected Chief Minister, and 5 other elected ministers. The Assembly comprised 25 elected members, the 3 official members in the Cabinet, and 4 members nominated by the Governor to represent commercial and minority interests. Although there was an elected majority in the Legislative Council, the Governor had tremendous reserve powers in all matters of defence, foreign affairs and internal security, and the right to suspend the constitution.

In anticipation of the elections in April 1955 under the Rendel Constitution, 3 new parties appeared on the scene - the People's Action Party, and the Labour Front in 1954, and the Democratic Party (which was popularly known as the Chinese Chamber of Commerce Party or the Tan Lark Sye Party) in 1955.

Mid 1954 I was drawing up a constitution for a new party for Lim Yew Hock when the President of the Progressive Party - the then leading Party in Singapore made a public statement to the effect that only fools or criminals would want complete internal self-government in under eight years. This so angered me that 1 accepted Lim Yew Hock's request to head the new Party in the hope of attracting some of the splinter groups from the Singapore Labour Party so that a cohesive socialist movement might have a strong voice in the new Legislative Assembly. Lim Yew Hock was then holding a nebulous position in the Overseas Chinese Banking Corporation, which I thought incompatible with the position of a trade union leader, so I persuaded him to leave his employ and gave him a job in my office. I then went to England for six weeks, to attach myself to Transport House for the study of the mechanies of electioncering.

The election campaign was an eye opener for our people - the English educatod were still apathetic and under the impression that this new constitution was still another phony dress rehearsal of an independence that would never come. I saw the campaign as a process of awakening the people and myself as an expendable bridge between the morass of colonial subjugation of the present and the firm land of independence of the morrow. To achieve maximum impact I chose to challenge in his constituency the leader of the Progressive Party, which was the leading political party.

The English language press made the mistake of castigating me daily because of the growing alarm of the business community. Since the Press was the only avenue to reach the people island wide, 1 kept up the pressure of daily provocative actions and speeches. receiving ever more rabid press reactions. The tactics worked, there was a slowly awakening response in the originally sceptical English-speaking and Chinesespeaking residents to our call for complete internal self-government and union with Malaya.

When the votes were in, 158,000 had voted and my party, the Labour Front, to our astonishment, emerged way ahead as the largest party. The P.A.P. with the support of students and pro-communist groups had 4 out of 5 fielded. It is illuminating 
to quote a statcment of Mr. Lee Kuan Yew at that time: "Any man in Singapore who wants to carry the Chinese speaking people with him cannot afford to be anti-communist."

The consternation of officialdom and the shock to the commercial community caused by the election results was considerable. The Rendel constitution was mainly tailored by the Progressive Party whom everybody and certainly the British expected to form the Government and to act as the gold-plated shock absorbers for imperialist rule. To the British the Rendel Constitution was a suave political play - a change of facade to quieten the screaming U.N.. and world opinion. It was not intended to make any basic change in the realities of government geared for British commercial exploitation.

In our efforts to form a government our first difficulty came when I insisted there must be a Malay in the Cabinet because I felt strongly that the Malays have been the Cinderella among our communities. Justice and good sense required that their rightful position be recognised from the outset. I considered it vital to the healthy development of Singapore that the Malays should be immediately drawn into the main stream of public life.

The barrage from hostile English press did not trouble me - my difficulty was the open contempt and obstructiveness of British officials; such as refusing to give me office accommodation until I threatened to set up a desk under a tree opposite the Treasury, a threat which so horrified them because of possible international press criticism that they finally gave me a cubicle under the stairs in the Legislative Assembly.

Of crucial import, however, was the refusal to allow me sight of internal security reports or even to permit me to know the general import. The argument, which was legally correct, was that under the Rendel Constitution the Governor was in charge of internal security - the Commissioner of Police reporting to him through the Colonial Secretary and neither Parliament nor elected members (including elected ministers) had a right to this information or any say in internal security. This aspect was high-lighted when, within a month of our taking office, a bus strike was manipulated into full fledged riot. The Communists were not interested in our efforts to liberalise trade union laws and work towards self-government. With the possibility of real power for themselves in the offing their aim was to create chaos and capture power through front organisations - riots were to be the means and workers and students the tools in this oft repeated strategy.

At the height of the Hock Lee Bus riots I was called in by the Governor, and in the presence of the Colonial Secretary and the Commissioner of Police, he suggested that I should request him to use British troops to "restore order". They refused to give me an analysis of the security position and the bloodshed that might be involved in "restoring order". To allay my anxiety the Governor did indicate that there was no immediate need for the use of troops but he wanted my official request so that he would act rapidly if need arose. My reply was simple: "I am prepared to take responsibility if I can have the information and the right to make an independent decision. I will not ask you to call in your troops to shoot our people on your say-so. If security information and decisions are your exclusive preserve constitutionally and factually - you must take the responsbility of your own acts or omissions." Some of you may remember the campaign of vilification in the press that resulted from my "refusal to call in the troops". I was made out to be a "coward", a "weakling", (this last was the contribution of Mr. Hoffman of the Straits Times at a press conference).

A little later a Singapore Harbour Board strike was blown up into a general strike that sought to cripple our daily life. I remember the agony of patience, of waiting for our people to learn and understand and reject communist sacrifice of the workers. To have used truncheons and bullets would have resulted in the chaos we sought to avoid and played into the hands of the enemy. The people of Singapore responded magnificently.

Then we had communist fomented troubled in Chinese secondary schools and communist organised seizure of school buildings. Once more I was met with an almost blank wall on the part of British officials when I sought information. The police were. 
seemingly very much taken by surprise and did not know how to cope. I believed the use of an unprepared police force would have resulted in bloodshed to a dangerous extent and would have antagonised our people against their government and destroyed a burgeoning hope in the possibility that existing partial democracy might lead us to freedom and healthy government. Instead of taking a "firm stand", I capitulated to the Chinese middle school students to a renewed press chorus of "coward".

I was so deeply disturbed by our inability to obtain any information on internal security that in 19551 once offered to Lee Kuan Yew that he should take over the Chief Ministership and I would seek to force the British to allow me to be Assistant Colonial Secretary so that at least one elected member in Government could know the mechanics of internal security. This he refused: "History shows no one who takes office before independence "ever retains office after".

Our next crisis was connected with the hated Emergency Regulations. Our Party wanted to repeal them. The Governor advised me to go ahead and repeal them and thereby gain credit for our Party with the people, and he would re-impose them under his reserve powers and take the odium. My sharp reaction to his well meant hypocrisy somewhat startled him. The Federation Government made strong representations pointing out that abolition of the Emergency Regulations would create an R. \& R. centre for communists in Singapore and would make Singapore a springboard for their activities in Malaya.

After anxious consideration we decided to abolish the Emergency Regulations and to replace some of them with the Preservation of Public Security Ordinance, which was to be for one year in order to give us time to understand better the realities of the Communist threat to us and to Malaya. In the P.P.S.O. we provided a Review Tribunal of two High Court judges and a district judge with power to cancel a detention order that they considered unjustified. The P.A.P. led a virulent mass campaign with public demonstrations against this measure.

Within 3 months of taking office it seemed clear to us that communism was gaining rapid ground with our workers and Chinese youth. Urgent measures had to be taken to counter this momentum if democracy were to have a chance - we were dealing with a runaway horse whom we could not stop but had to deflect to the right road.

Our oaly road was education of our people through the press and radio. The Legislative Assembly sat for several days in every month, and in August 1955 came a heaven-sent opportunity. The Governor refused to appoint four Assistant Ministers I nominated. We worked this issue into a major constitutional crisis to keep up the pressure to expedite the grant of complete internal self government and we succeeded in extracting from the British a consent to review the Rendel Constitution after one year's experience, i.e. in 1956.

We introduced weekly "Meet the People" sessions with enthusiastic press coverage. These sessions went some way to break the frozen ground of Civil Service arrogance and to make our people understand that this was their government and they were their servants. We organised a mass signature campaign for Merdeka. We appointed a Malayanisation Commission and put at its head a very able and dedicated man, Dr. Sreenivasan even though we believed he was in the P.A.P. camp. The public hearings and magnificent report of this Commission infused fresh hope in our people and are the watershed of our present Civil Service.

It was Tan Lark Sye who, with stubborn missionary fervour, taught me to understand the need of our Chinese for citizenship and multi-lingualism. He deserves a public monument. We introduced multi-lingualism in the Assembly and multi-lingual streams of education. We incorporated liberal citizenship provisions in our constitutional demands, despite heavy P.A.P. opposition, and persuaded the British government to accept them.

In October 1955 I led a Trade Mission to Indonesia, which gained for us political support and Indonesian goodwill and was successful beyond expectations. In December 1955 there was a meeting in Baling between Tengku Abdul Rahman, Tan Cheng Lock, myself, and the Communist leaders led by Tan Chin Peng. Although we failed to persuade the Communists to lay down their arms and come out of the jungle, I learnt at that meeting a new respect for the Prime Minister of Malaya because of the 
humanity and breadth of vision he displayed. This genuine respect led to happy cooperation between our two territories.

Also in December I went to London via Delhi to prepare for the fateful April 1956 Conference. We received warm encouragement from Nehru and Krishna Menon. At this December 1955 meeting I made an official request to Lennox Boyd that the British Government should use its good offices with the governments of the Federation of Malaya and the States of Sarawak, Brunei and North Borneo and to urge consideration of a federation of all these territories. I received from the Secretary of State for the Colonies a coldly angry reply to the effect that these were matters for the people of the territories concerned in which H.M. Government would not consider it appropriate to intervene.

We took an all-Party Mission to London for the Constitutional Conference in April/May 1956, seven government members and six opposition, because to me independence was not a party matter. There were considerable concessions made by the British- we would be a self-governing state within the Commonuealth with Singapore citizenship for those born, or of long residence, in Singapore, a fully elected legislature and fully elected Cabinet which would have control of internal security, and Malayanisation of the civil service. Foreign affairs and defence were to be reserved fields in which the British should have exclusive say. A difficulty arose over internal security which the British wanted to control through a Committee on which they had the majority. On the last day of the talks at a pre-conference meeting eleven of us voted in favour of this final offer and two against: $\operatorname{Lim}$ Chin Siong and 1 . 1 then agreed to sign acceptance of the proposed new constitution in deference to the majority will and to return to Singapore to explain my position and resign, as I could not in conscience agree to a constitution which by giving the British control of internal security deprived us of the reality of internal self-government. Lee Kuan Yew would not have it that he should be placed in a position of being less intransigent than 1 and we ended voting solidly, except for the Progressive Party members, against the proposals and at the conference table rejected them.

I made one further effort at agreement with Lennox Boyd, not knowing he had already lined up the next government. My objection to the constitution was that like Oliver Twist we would have to come back for more shortly and this would antagonise the British - we could not afford to antagonise the British - fundamentally we were on the same side. I wanted a constitution providing genuine internal self-government within the Commonwealth, and thereafter in partnership with the British we could turn our full attention to the communist threat - the sole remaining obstacle to full independence. Lennox Boyd was no longer in a mood to listen - he was on his way to a yachting holiday.

In June 1956 I resigned. Two days after my resignation Mr. Lim Yew Hock formed a new government as planned by Lennox Boyd whilst we were still in London. Within months the "Caretaker government" of Lim Yew Hock faced communist-mounted strikes and seizure of school buildings by Chinese middle school students. He ordered, and the police implemented, vigorous measures of arrest, detention and physical re-occupation of schools. What the police were seemingly unprepared for in mid 1956 they were ready to cope with in October 1956.

In March 1957 another all-Party Mission led by Lim Yew Hock went to London and this time accepted what was basically the same constitution which we had rejected the previous year.

In August 1957 we had the significent spectacle of the Lee Kuan Yew group losing control of the P.A.P. to the extremists. Adroit manoeuvring and the arrest and detention of some P.A.P. leaders by Lim Yew Hock saved the day and returned the Lee Kuan Yew group to leadership of their party which at that time had a total membership of approximately 4,800 .

At the 1959 elections with an electorate of 590,000, including the new Chinese citizens, the P.A.P. emerged as the only well organised and stable Party with a total of $54 \%$ of the votes and 43 seats out of the 51 constituencies in every one of which they had fielded candidates. 